\title{
Sensory and sympathetic nerve fibers undergo sprouting and neuroma formation in the painful arthritic joint of geriatric mice
}

\author{
Juan M Jimenez-Andrade ${ }^{1,2}$ and Patrick W Mantyh ${ }^{1,3,4^{*}}$
}

\begin{abstract}
Introduction: Although the prevalence of arthritis dramatically increases with age, the great majority of preclinical studies concerning the mechanisms that drive arthritic joint pain have been performed in young animals. One mechanism hypothesized to contribute to arthritic pain is ectopic nerve sprouting; however, neuroplasticity is generally thought to be greater in young versus old nerves. Here we explore whether sensory and sympathetic nerve fibers can undergo a significant ectopic nerve remodeling in the painful arthritic knee joint of geriatric mice.

Methods: Vehicle (saline) or complete Freund's adjuvant (CFA) was injected into the knee joint of 27- to 29month-old female mice. Pain behaviors, macrophage infiltration, neovascularization, and the sprouting of sensory and sympathetic nerve fibers were then assessed 28 days later, when significant knee-joint pain was present. Knee joints were processed for immunohistochemistry by using antibodies raised against CD68 (monocytes/ macrophages), PECAM (endothelial cells), calcitonin gene-related peptide (CGRP; sensory nerve fibers), neurofilament 200 kDa (NF200; sensory nerve fibers), tyrosine hydroxylase (TH; sympathetic nerve fibers), and growth-associated protein 43 (GAP43; nerve fibers undergoing sprouting).

Results: At 4 weeks after initial injection, CFA-injected mice displayed robust pain-related behaviors (which included flinching, guarding, impaired limb use, and reduced weight bearing), whereas animals injected with vehicle alone displayed no significant pain-related behaviors. Similarly, in the CFA-injected knee joint, but not in the vehicle-injected knee joint, a remarkable increase was noted in the number of $\mathrm{CD}^{+} 8^{+}$macrophages, density of

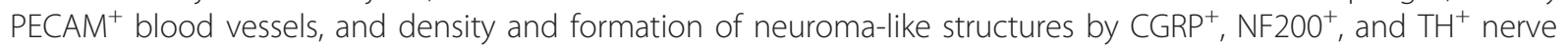
fibers in the synovium and periosteum.

Conclusions: Sensory and sympathetic nerve fibers that innervate the aged knee joint clearly maintain the capacity for robust nerve sprouting and formation of neuroma-like structures after inflammation/injury. Understanding the factors that drive this neuroplasticity, whether this pathologic reorganization of nerve fibers contributes to chronic joint pain, and how the phenotype of sensory and sympathetic nerves changes with age may provide pharmacologic insight and targets for better controlling aging-related joint pain.
\end{abstract}

\section{Introduction}

The prevalence of arthritis generally increases with age and is frequently accompanied by significant joint pain [1-5]. In individuals with arthritis (for example, rheumatoid arthritis (RA), osteoarthritis (OA)), joint pain generally decreases the functional status and quality of life, as it is strongly associated with physical disability,

\footnotetext{
* Correspondence: pmantyh@email.arizona.edu

'Department of Pharmacology, University of Arizona, 1501 N. Campbell

Avenue, Tucson, AZ 85724, USA

Full list of author information is available at the end of the article
}

decreased mobility, depression, sleep disturbances, and increased health care costs [1,2,6-9]. Currently, we know relatively little about the mechanisms that drive arthritic joint pain. This is reflected in the fact that we have remarkably few effective analgesic therapies for treating joint pain that are not accompanied by significant unwanted side effects [1,10-12]. As the life expectancy of humans continues to increase in both the developing and developed world [13,14], age-related arthritic joint pain is expected to exact an ever-increasing toll on aged individuals and society. 
Arthritic joint pain most frequently occurs with movement and/or loading of the affected joint but can also be present at rest $[15,16]$. Movement or loading-induced joint pain is usually described as sharp and/or stabbing, whereas arthritic joint pain at rest is usually described as burning and/or throbbing, with occasional bouts of stabbing pain [15-17]. Currently, it is believed that spontaneous arthritic pain (joint pain at rest) and movementevoked pain are largely driven by joint injury and/or inflammation, which induces both a peripheral sensitization (an increase of sensitivity of nociceptive primary afferent neurons) and central sensitization (hyperexcitability of neurons conveying nociceptive information in the central nervous system (CNS)) (see [1,18-20] for review). However, it remains largely unknown why a relatively poor correlation exists in OA between the radiologic signs of arthritis (for example, joint-space narrowing, erosive changes) and the severity of arthritic pain $[1,2,21]$ as well as the specific mechanisms that drive spontaneous versus movement-evoked arthritic joint pain in OA. This dissociation between pain and disease progression is also observed in RA, as even therapies such as tumor necrosis factor- $\alpha$ inhibitors that can be quite effective at decreasing the severity of joint inflammation/swelling in RA are generally much less efficacious at attenuating RA pain [22].

One potential mechanism that may explain the dissociation between disease progression and pain in arthritis is that an active and ectopic sprouting of sensory and sympathetic nerve fibers plays a role in driving pain due to arthritis. For example, a previous study performed in young rats suggested that after injection of complete Freund adjuvant (CFA) into the temporomandibular joint of rats, significant sprouting of sensory nerve fibers occurred in the painful arthritic joint [23]. However, as aging is generally associated with a decline and deterioration of the ability of tissues to grow (with the exception of cancers) [24-27], it is not clear whether sensory or sympathetic neurons in aged animals retain the ability to undergo exuberant ectopic sprouting, and if so, whether sprouting is relevant to understanding the mechanisms that drive pain in the aged arthritic joint.

In this study, we examined the ability of sensory and sympathetic nerve fibers to undergo ectopic sprouting. The model used here was generated by unilaterally injecting CFA into the articular space of the knee joint of geriatric (27- to 29-month-old) female mice. With this model, we demonstrate that even in the arthritic knee joint of these geriatric mice, robust sprouting and formation of neuroma-like structures by both sensory and sympathetic nerve fibers was observed in all CFAinjected animals and in none of the vehicle-injected mice. These newly sprouted sensory and sympathetic nerve fibers were not only present in a higher density per unit area than was ever found in the normal aged joint, but were also found in areas of the joint that are normally poorly or not innervated.

\section{Materials and methods \\ Animals}

Experiments were performed on a total of 12 geriatric female $\mathrm{B} 6 / \mathrm{C} 3 \mathrm{H}$ mice (a generous gift from Rinat-Pfizer, San Francisco, CA, USA). Mice were received at our animal care facilities 2 months before experiments were performed. At the time of initiation of the experiments, mice were 27 to 29 months old. The mice were housed in accordance with the National Institutes of Health guidelines under specific pathogen-free conditions in autoclaved cages maintained at $22^{\circ} \mathrm{C}$ with a 12 -hour alternating light-and-dark cycle and were given autoclaved food and water ad libitum. The Institutional Animal Care and Use Committee at the Minneapolis VA Medical Center approved all procedures.

\section{Complete Freund's adjuvant injection}

A modified version of a previously validated model of arthritic inflammation of the knee joint [28] was produced by performing four intraarticular injections of complete Freund's adjuvant (CFA) dissolved in saline or saline alone (vehicle) at days $0,7,14$, and 21 unilaterallly into the left-knee joint. At days 0 and 7 , mice received $5 \mu \mathrm{l}$ of CFA $(1 \mu \mathrm{g} / \mu \mathrm{l})$, and at days 14 and 21 , mice received $10 \mu \mathrm{l}$ of CFA $(1 \mu \mathrm{g} / \mu \mathrm{l})$. Mice treated with vehicle received the same injection volume of saline. In brief, mice were anesthetized by using $2 \%$ to $3 \%$ isoflurane mixed with air. An injection of CFA was given by using a 30-gauge, 1/2-inch needle that was fitted with cannulation tubing such that only $2.5 \mathrm{~mm}$ of the needle was allowed to puncture the joint. CFA or saline (vehicle) was injected through the patellar ligament into the articular space, by using the femoral condyles as a guide.

Currently, there is no well-accepted rat or mouse model of osteoarthritis (OA) simultaneously induces robust joint destruction and pain similar to that observed in humans with painful OA. One rodent model that has been used as a surrogate in terms of OA pain is CFA injection into the knee joint. As previous results from this model [29] were used to guide the human trials of anti-NGF (which proved highly efficacious in reducing human OA pain [30]), we chose to use this model to examine potential nerve sprouting in the painful inflamed knee joint. However, it is important to note that although pain behaviors were present at 4 weeks after injection, no signs were seen of significant cartilage destruction and osteophyte formation, as evaluated with histologic analysis in the knee joint. This result contrasts with the pathology reported in preclinical models of OA, including intraarticular injection of 
monoiodoacetate or surgical destabilization of the joint. Additionally, in our hands, CFA injections caused infiltration of $\mathrm{CD} 68^{+}$monocytes/macrophages into the synovial membrane as well as tissues outside the joint, including tendons, ligaments, and surrounding muscle (data not shown). Taken together, these results suggest that the present model involves an inflammation in the synovium as well as the tendons and ligaments of the CFA-injected knee joint without signs of cartilage destruction.

\section{Behavioral measures of arthritic joint pain}

Behavioral measures of arthritic joint pain included spontaneous pain (guarding and flinching), stimulusevoked pain (limb use), and the ability of the animal to place weight on the arthritic limb versus the nonarthritic limb while ambulatory (dynamic weight bearing). In brief, the number of hindpaw flinches and time spent guarding were recorded as measures of spontaneous pain, as these measures mirror patients in a clinical setting with arthritis who have spontaneous pain (joint pain at rest) $[15,31]$. The number of spontaneous flinches and time spent guarding, representative of spontaneous nocifensive behavior, were recorded during a 2-minute observation period, as previously described [32-38]. Flinches were defined as the number of times the animal raised its hindpaw and guarding as the amount of time animals held the hindpaw aloft while not ambulatory. Based on our previous experience evaluating spontaneous pain-related behaviors in mice, three or more flinches and two or more seconds spent guarding during a 2-minute interval suggest the presence of pain-related behaviors.

Normal limb use during spontaneous ambulation in an open field was used as an indicator of stimulusevoked pain and was scored on a scale of 5 to 0 , as previously reported [34,38], where (5) is normal use, (4) is partial limp, but not pronounced, (3) is pronounced limp, (2) is limp and guarding behavior, (1) is partial nonuse of limb in locomotor activity, and (0) is complete lack of limb use. One trial of approximately 1 to 2 minutes was performed per test period. Evaluation of normal limb use during ambulation was performed to reflect the clinical condition when patients with arthritis have pain after movement of the joint [15,31].

Behavioral measures of arthritic joint pain included spontaneous pain (guarding and flinching) and stimulusevoked pain (limb use) were performed at day 28 after CFA initial injection, whereas dynamic weight bearing was determined at day 23 after initial injection. Not enough time was available in a single day to perform all four behaviors.

Dynamic weight-bearing analysis of the arthritic limb was performed on days 0 and 23 after initial intraarticular CFA injection with the use of a Dynamic Weight Bearing device (EB Instruments, Pinellas Park, Florida, USA). Similar pedobarographic analysis is used clinically to determine the weight bearing of patients with arthritic knee joints [39]. The mouse was allowed to move freely on the electronic sensor pad within the apparatus for 5 minutes, and the sensor-captured weight-bearing information was transmitted live to a computer. By using a synchronized video recording of the test and the scaled map of the detected zones, each presumed paw detection was validated by an observer and identified as a left or right and fore- or hindpaw. Dynamic weight bearing on the affected (left) hindlimb was calculated and reported as a percentage of total weight bearing on both hindlimbs.

\section{Immunohistochemistry}

At day 28 after initial CFA injection, mice were deeply anesthetized with carbon dioxide asphyxiation, delivered by using a compressed gas cylinder, and perfused intracardially with $20 \mathrm{ml}$ of $0.1 \mathrm{M}$ phosphate-buffered saline (PBS; pH 7.4 at $4{ }^{\circ} \mathrm{C}$ ) followed by $30 \mathrm{ml}$ of $4 \%$ formaldehyde/12.5\% picric acid solution in $0.1 \mathrm{MPBS}(\mathrm{pH} 6.9$ at $4^{\circ} \mathrm{C}$ ). Ipsilateral and contralateral knee joints were harvested after perfusion and postfixed for at least 12 hours in the same perfusion fixative. The process of postfixing, decalcification, and sectioning of the bones/joints was performed as previously described $[40,41]$.

To qualitatively assess the changes in the density and morphology of sensory nerve fibers that innervate the knee joint, the macrophage infiltration, and neovascularization of the synovium, $20 \mu \mathrm{m}$-thick frozen sections of the bone/joint were processed according to our previously published procedures $[35,40,41]$. Frozen bone/ knee-joint sections were incubated with an antibody against calcitonin gene-related peptide (CGRP, polyclonal rabbit anti-rat CGRP; 1:10,000; Sigma Chemical Co. St Louis, MO, USA; catalog no. C8198) to label primary afferent sensory nerve fibers, an antibody against neurofilament $200 \mathrm{kDa}$ (NF200, chicken anti-neurofilament 200 kDa; NF200, 1:5,000; Neuromics, Edina, MN, USA; catalog no. $\mathrm{CH} 22104)$ to label myelinated primary afferent sensory nerve fibers. Sympathetic nerve fibers were labeled with an antibody against tyrosine hydroxylase ( $\mathrm{TH}$, polyclonal rabbit anti-rat $\mathrm{TH}, 1: 1,000$; Chemicon, Billerica, MA, USA; catalog no. AB152). Sprouted nerve fibers were labeled with an antibody against growthassociated protein-43 (GAP-43, rabbit anti-GAP43, 1:1,000; Millipore, Billerica, MA, USA; catalog no. AB5220). Blood vessels were labeled with an antibody against platelet endothelial cell adhesion molecule (rat anti-mouse PECAM, 1:500, BD PharMingen, San Jose, CA, USA; catalog no. 550274). Monocytes/macrophages were indentified with an antibody against a myeloid 
glycoprotein (rat anti-mouse CD68; 1:2,000, AbD Serotec, Raleigh, NC, USA; catalog no. MCA1957). Additionally, four to five sequential frozen bone sections were cut at $10 \mu \mathrm{m}$ thick and were stained with safranin-O/ fast green to visualize gross pathologic changes in cartilage and bone induced by CFA.

\section{Quantification of nerve fiber density, sprouting, macrophage infiltration and neovascularization}

Approximately 30 separate, 20 - $\mu$ m-thick frozen sections were obtained from the knee joint of each mouse. Three confocal images (Olympus America Inc, Center Valley, PA, USA; software v. 5.0) from different sections separated by at least $100 \mu \mathrm{m}$ were obtained for each marker. Sections were initially scanned at low magnification $(\times 100)$ to identify areas with the highest capillary or nervefiber density in the synovium. These areas in the synovium were defined as "hot spots." One image per section was acquired within the medial synovial hot spot. Whereas nerve fibers, blood vessels, and macrophages were observed throughout the inflamed synovium, neovascularization and nerve sprouting was consistently present in the synovium adjacent to the meniscus, therefore, most of the hot spots were found and quantified in this area. In the knee sections from naïve and sham mice, no evidence of "hot spots" was noted in terms of significant changes in the morphology or density of nerve fibers and blood vessels.

The volume of CFA-inflamed synovium analyzed was $315 \mu \mathrm{m}$ (length), $315 \mu \mathrm{m}$ (width), and $20 \mu \mathrm{m}$ (depth). The Z-stacked images were analyzed with Image-Pro Plus v. 6.0 (Media Cybernetics, Bethesda, MD, USA), and nerve fibers and blood vessels were manually traced to determine their respective lengths. To determine whether a structure in the image was a nerve-fiber profile, simultaneous observations of the image on a highresolution computer monitor and the section viewed in the microscope were performed. The fine focus of the microscope was used to follow the fibers across the entire thickness of the knee section. Structures were considered nerve profiles only if their signal was at least 3 times greater than background signal, if their length was $>20 \mu \mathrm{m}$, and if they displayed the presence of dilatations (varicosities). Small dot-like structures were not counted, even though these structures likely represented cut fibers. Nerve sprouting or neovascularization was reported as density of nerve fibers or blood vessels per volume of synovium $\left(\mathrm{mm} / \mathrm{mm}^{3}\right)$ [40]. CD68 ${ }^{+}$macrophages were quantified in each layer of the inflamed synovium from z-series images ( $\times 400$ magnification) of each field of view by using Imaris Pro Software v. 6.0 (Bitplane AG, South Windsor, CT, USA). Only CD68 ${ }^{+}$ cells that displayed visible nuclei, as determined by counterstaining with DAPI, were counted. Only CD68 ${ }^{+}$ macrophages/monocytes located in the normal or inflamed synovium were quantified. Macrophages/ monocytes were defined as $\mathrm{CD}^{+} 8^{+}$profiles that were distant from any bone surface, whereas osteoclasts were defined as $\mathrm{CD} 8^{+}$profiles that were directly apposed to mineralized bone $[42,43]$.

Data from at least three slices per knee joint were recorded and averaged. The total number of $\mathrm{CD}^{+} 8^{+}$ macrophages in the synovium was reported. Total volume of the synovium (naive and inflamed) was calculated by tracing the area of the synovium and multiplying this area by the thickness of the section $(20 \mu \mathrm{m})$.

Density of nerve fibers, PECAM ${ }^{+}$blood vessels and $\mathrm{CD} 8^{+}$monocytes/macrophages in the femoral periosteum were calculated within the distal metaphysic, as significant neural remodeling was observed in this region. The area evaluated in frozen sections was within a 1.0$\mathrm{mm}$-long region, which started $0.5 \mathrm{~mm}$ below the distal femoral growth plate. For frozen sections, the average volume of periosteum analyzed was $315 \mu \mathrm{m}$ (length), 50 $\mu \mathrm{m}$ (width), and $20 \mu \mathrm{m}$ (depth). The confocal images were viewed on a high-resolution monitor, and the length of nerve fibers was determined by manually tracing the nerve or blood vessel profile by using Image Pro Plus v. 6.0 image analysis software (Media Cybernetics, Bethesda, MD, USA). Nerve sprouting or neovascularization was reported as density of nerve fibers or blood vessels per volume of periosteum $\left(\mathrm{mm} / \mathrm{mm}^{3}\right)$. Data from at least three slices per knee joint were recorded and averaged. $\mathrm{CD} 8^{+}$macrophages were quantified in both layers of the periosteum from z-series images of each field by using Imaris Pro-Software v. 6.0 (Bitplane AG, South Windsor, CT, USA). The density of $\mathrm{CD}^{+} 8^{+}$macrophages in the periosteum was reported as number of $\mathrm{CD} 68^{+}$ macrophages per volume of periosteum.

To determine whether changes were present in the density of nerve fibers or the formation of neuroma-like structures, frozen sections were examined at low magnification with an epifluorescent microscope. Areas that were examined included the lower half of the femur and the upper half of the tibia and included the mineralized bone, bone marrow, cartilaginous knee joint, synovium, periosteum, and knee-joint ligaments. In general, areas that contained sprouting of nerve fibers and neuromalike structures were remarkably different from nerve fibers in the normal bone and joint in terms of morphology and density. For example, a neuroma-like structure was defined as a disordered mass of axons $\left(\mathrm{CGRP}^{+}\right.$, $\mathrm{NF}_{200^{+}}$) that has an interlacing and/or whirling morphology, a size that is at least $10 \mu \mathrm{m}$ thick by $70 \mu \mathrm{m}$ long (> 10 individual axons) [44-46], and that we have never observed in any bone or joint compartment, including the synovium or periosteum of normal joint or bone [41,47-49]. 


\section{Statistics}

A $t$ test was used to compare the behavioral measures of spontaneous pain (guarding and flinching) and dynamic weight bearing. The Mann-Whitney Rank Sum Test was used to compare the stimulus-evoked pain (limb use). One-way ANOVA followed by the Dunnett post hoc test was used for the immunohistochemical measures between the experimental groups. Significance level was set at $P<0.05$. In all cases, the investigator responsible for behavioral testing, plotting, measuring, and counting was blind to the experimental situation of each animal.

\section{Results}

CFA injection into the knee joint of geriatric mice produces significant pain-related behaviors

Pain-related behaviors were evaluated in CFA-injected animals as compared with saline-treated animals. Assessment of arthritic joint pain-related behaviors, including spontaneous guarding and flinching, and limbuse analysis of the hindlimb was performed on day 28 after initial intraarticular CFA injection, and dynamic weight-bearing analysis was performed on day 23 after initial intraarticular CFA injection (Figure 1). At day 28 post-injection, CFA-treated mice exhibited a greater time spent guarding, and number of flinches as compared to those observed in vehicle-treated mice (Figure 1 ). Additionally, the evaluation of ambulatory pain revealed that the mean score of limb use was reduced from a $4.3 \pm 0.1$ in vehicle-treated mice to $2.7 \pm 0.11$ in CFA-treated mice at day 28 after cell injection. Similarly, CFA-induced arthritis resulted in a significant reduction in dynamic weight bearing of the CFA-injected hindlimb, as compared with the vehicle-treated hindlimb (Figure 1).

\section{CFA injection into the knee joint of geriatric mice} produces joint edema, infiltration of macrophages, and aberrant neovascularization in the synovium

Repeated injections of CFA resulted in significant edema within the knee joint at day 28 after initial injection. In all CFA-injected mice, the inflammation was restricted to the ipsilateral joint with no evidence of inflammation present in the contralateral hindlimb.

CFA-induced changes in structures of the knee joint, including bone, synovium, and periosteum were examined with histology (safranin-O/fast green staining) and immunonohistochemistry. At day 28 after initial injection, the repeated intraarticular injection of vehicle did not induce a visible inflammatory response in the synovium (Figure $2 \mathrm{~B}$ ) or major changes in the structure of articular cartilage (femur and tibia). The knee sections from vehicle-treated mice and mice without injection (naïve) were similar in appearance. In contrast, repeated injections of CFA into the knee induced an extensive inflammation in the synovial membrane and thickening of the joint capsule (Figure 2A, C). Repeated CFA injections caused the infiltration of many $\mathrm{CD}^{+} 8^{+}$monocytes/ macrophages into the synovial membrane (Figure 2E) and tissues outside the joint (periarticular inflammation) including tendons, ligaments, and surrounding muscle (data not shown). Knee sections stained with antibody that recognizes endothelial cells found in blood vessels (PECAM), showed few small blood vessels in the synovial membrane (Figure $2 \mathrm{~F}$ ) of vehicle-treated mice. In contrast, CFA injection induced an increase in the number of PECAM $^{+}$blood vessels, which were different from those that vascularize normal synovium, as they were thicker and exhibited disorganized, nonlinear morphology (Figure 2G).

Quantitative image analysis revealed an increase in the volume of the synovial membrane during arthritis from $0.0044 \pm 0.0003 \mathrm{~mm}^{3}$ in vehicle-treated knees to 0.1454 $\pm 0.0186 \mathrm{~mm}^{3}$ on Day 28 in CFA-treated knees (Figure 3A). A significant increase in the density of $\mathrm{PECAM}^{+}$ blood vessels was present in CFA-treated knees as compared with vehicle-treated or naïve knees (Figure 3B). The $\mathrm{CD} 8^{+}$monocyte/macrophage density in the synovium of CFA-treated knees was not significantly different as compared with the synovium from vehicle-treated knees (Figure $3 \mathrm{C}$ ). When the total number of $\mathrm{CD}^{+} 8^{+}$ monocytes/macrophages in the synovium was calculated as the product of cell density and synovial volume, the normalized total cell number in the synovium was significantly greater in CFA-treated mice (11 $007 \pm 1,125$ $\mathrm{CD} 8^{+}$profiles) as compared with vehicle-treated (365 \pm $63 \mathrm{CD} 8^{+}$profiles $)$or naïve mice $\left(301 \pm 42 \mathrm{CD}^{+} 8^{+}\right.$ profiles).

\section{CFA injection into the knee joint of geriatric mice} produces sprouting and formation of neuroma-like structures by sensory and sympathetic nerve fibers in the synovium and periosteum

$\mathrm{CGRP}^{+}$(sensory, Figure 4B), NF200 ${ }^{+}$(sensory, Figure 4D), $\mathrm{TH}^{+}$(sympathetic), and $\mathrm{GAP} 3^{+}$(nerve fibers undergoing sprouting; Figure 4I) nerve fibers were evident only at low levels in the synovial-meniscal interface from vehicle-treated knee sections (Figure 4B, D, F, H). In contrast, 28 days after the initial CFA injection, a

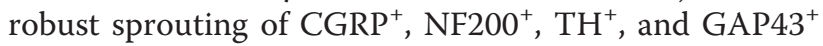
nerve fibers was observed within the synovium of the inflamed joint (Figure 4C, E). These newly sprouted nerve fibers are found in higher density (Figure 5) and have a highly disorganized appearance as compared with the primarily linear morphology of these nerve fibers in the synovium of vehicle-treated or naïve mice. Whereas $100 \%$ of CFA-injected mice showed significant sprouting of $\mathrm{CGRP}^{+}, \mathrm{NF}_{200}{ }^{+}, \mathrm{GAP}_{4} 3^{+}$, and $\mathrm{TH}^{+}$nerve fibers, five of six mice had two to three neuroma-like structures in 


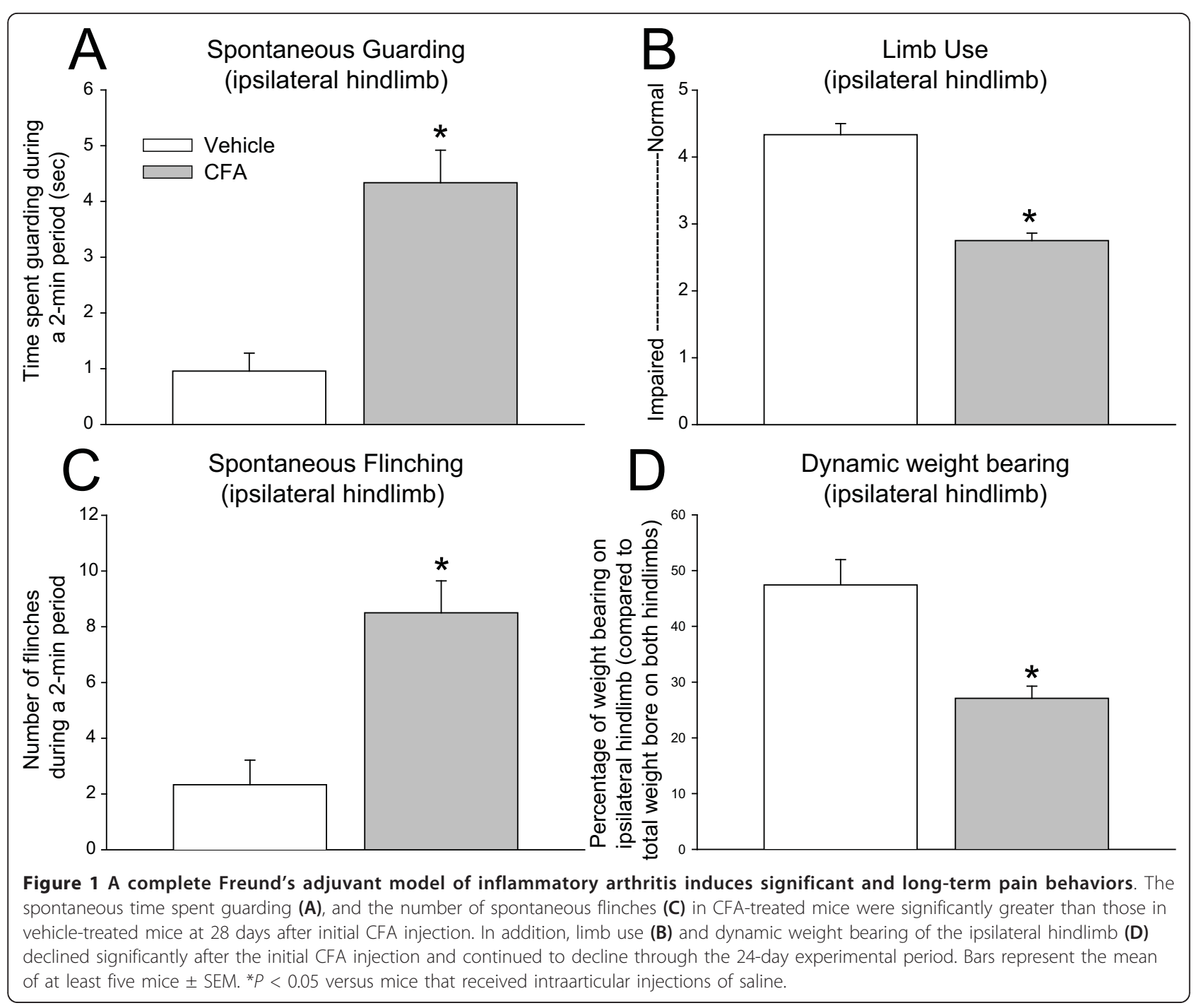

the synovium (Figure 4G). Only one of six mice displayed a large neuroma (approximate thickness of 50 $\mu \mathrm{m})$. These neuroma-like structures appear as a disordered mass of blind-ending axons that have an interlacing or whirling morphology and are never observed in vehicle-treated mice (Figure 4F).

To determine whether the nerve sprouting induced by the arthritis was present in other knee-joint compartments, we qualitatively examined cartilage, synovium, cortical bone, trabecular bone, marrow space, ligaments, and periosteum. Sensory and sympathetic nerve fibers were present in these compartments, as previously described [48-54], however, a noticeable change in the density of sensory and sympathetic nerve fibers and/or neuroma formation was observed only in the synovium and periosteum of inflamed knee joints. Confocal micrographs of metaphyseal periosteum preparations from vehicle-treated mice revealed that $\mathrm{CGRP}^{+}$(Figure 6B) and $\mathrm{NF}^{200^{+}}$(Figure 6D) nerve fibers normally have a linear and bifurcating pattern. In contrast, periosteal preparations from CFA-treated mice displayed an aberrant and disorganized morphology of $\mathrm{CGRP}^{+}$(Figure 6C), $\mathrm{NF}^{200^{+}}$(Figure 6E) sensory nerve fibers. The majority of $\mathrm{TH}^{+}$sympathetic fibers in the periosteum of vehicle-treated mice possessed a unique "corkscrew" morphology that appeared to wrap around small blood vessels in the periosteum (Figure 6F). In contrast, in the periosteum of CFA-treated mice $\mathrm{TH}^{+}$nerve fibers displayed a highly pathologic and disorganized pattern of innervation as well as appearing to wrap large blood vessels in a tight corkscrew-like fashion (Figure 6G). Additionally, five of six mice treated with CFA had two to three neuroma-like structures in the periosteum (Figure 6I).

Quantitative analysis of the density of nerve fibers (expressed as length of nerve fibers $/ \mathrm{mm}^{3}$ of femoral periosteum) revealed that CFA-induced knee arthritis 


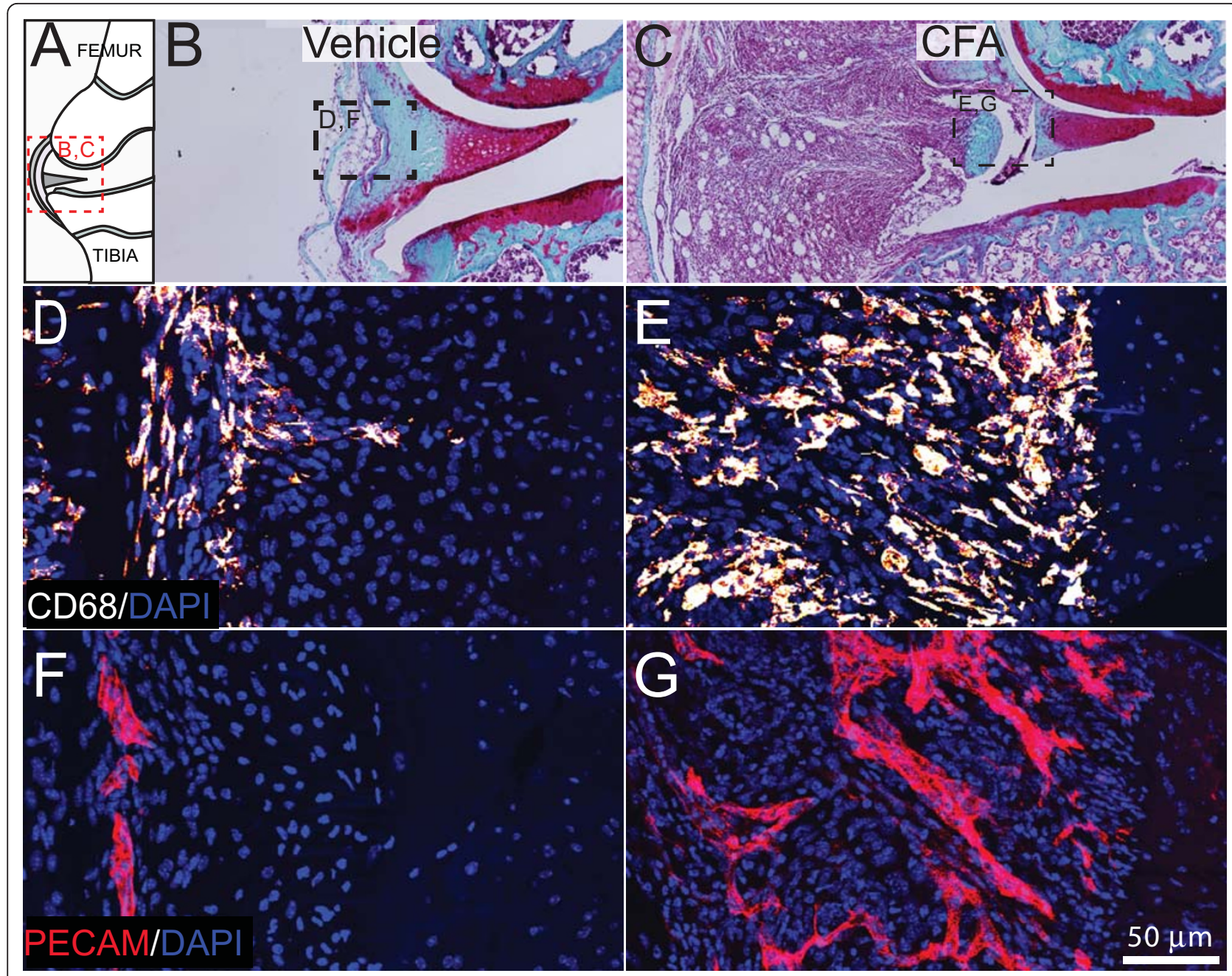

Figure 2 CFA injection into the geriatric knee joint induces synovial inflammation, macrophage infiltration, and neovascularization. (A) Schematic of the frontal view of a cross-sectioned mouse knee joint, indicating the location of the major cellular and structural changes occurring in the arthritic knee joint. (B-G) Longitudinal cross sections (10 $\mu \mathrm{m}$ thick) of the knee joint stained with safranin-O/fast green display the histopathologic changes in the synovium and capsule 28 days after initial injection of complete Freund's adjuvant (CFA). In the vehicleinjected mice, the synovium is very thin and relatively intact (B), whereas in CFA-injected mice, an extensive inflammation in the synovial membrane and thickening of the joint capsule are found $(\mathbf{C})$. The outlined boxes in B and C illustrate the region from which the subsequent confocal images were obtained. Representative confocal images of $\mathrm{CD} 8^{+}$macrophages ( $\mathbf{D}, \mathbf{E}$, red/orange), DAPI-labeled nuclei (blue), and a vascular endothelial marker, $\operatorname{PECAM}^{+}(F, G, r e d)$ in vehicle-injected $(\mathbf{D}, \mathbf{F})$ and CFA-injected $(\mathbf{E}, \mathbf{G})$ mouse knee-joint sections $(20$ um-thick). Injections of CFA induce a significant infiltration of $C D 68^{+}$macrophages into the synovium (E), as compared with vehicle-treated mice (D). In vehicle-injected mice, a low-level vascularization by PECAM ${ }^{+}$vessels is observed in the synovial space of the knee joint (F). In contrast, in CFAtreated knee joints, a significant number of $\mathrm{PECAM}^{+}$vessels have developed and have an enlarged and disorganized morphology (G), as compared with vehicle-treated mice.

resulted in a significant increase in the density of CGRP + fibers as compared with mice treated with vehicle $\left(3,314.9 \pm 377\right.$ versus $\left.2,085 \pm 380 \mathrm{~mm} / \mathrm{mm}^{3} ; P<0.05\right)$. Likewise, the density of NF200 ${ }^{+}$sensory nerve fibers in the femoral periosteum was significantly increased in CFA-treated mice as compared with vehicle-treated $\left(3,944 \pm 1,176\right.$ versus $\left.1,144 \pm 160 \mathrm{~mm} / \mathrm{mm}^{3} ; P<0.05\right)$. Similarly, the density of postganglionic $\mathrm{TH}^{+}$sympathetic nerve fibers increased significantly in the femoral periosteum of mice treated with CFA as compared with vehicle-treated mice $(3,392 \pm 291$ versus $1,020 \pm 64$ $\left.\mathrm{mm} / \mathrm{mm}^{3} ; P<0.05\right)$. Finally, the density of nerve fibers undergoing sprouting $\left(\mathrm{GAP}_{4} 3^{+}\right)$also increased significantly in the femoral periosteum of mice that received intraarticular injections of CFA as compared with mice injected with vehicle $(4,677 \pm 805$ versus $1,596 \pm 261$ $\left.\mathrm{mm} / \mathrm{mm}^{3} ; P<0.05\right)$. The density of nerve fibers in the periosteum of vehicle-treated mice was not significantly different when compared with femoral periosteum of naïve mice (data not shown). 


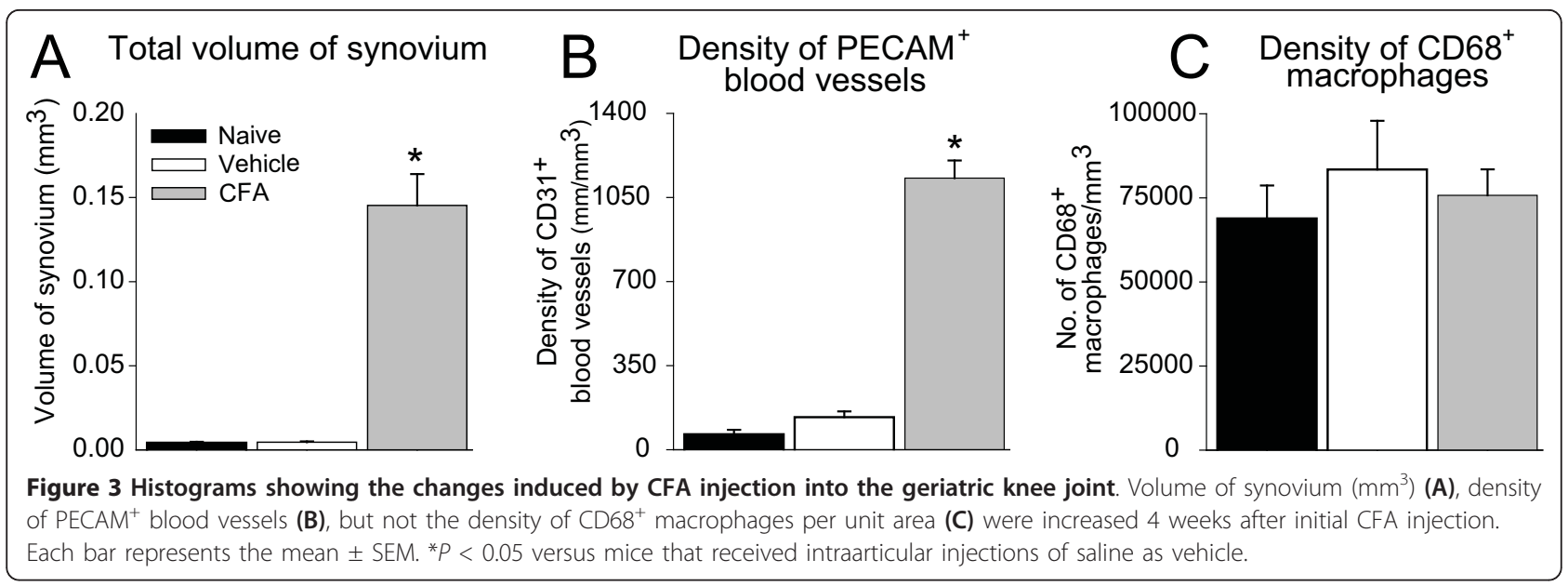

\section{Discussion}

\section{Age, arthritis, and joint pain}

Although chronic joint pain can be caused by a diverse group of injuries and disorders, what most forms of arthritis have in common is that the prevalence increases with age and is frequently accompanied by significant pain and impairment of physical function [1-6,55]. Unfortunately, management of age-related skeletal pain can be difficult, as current therapies are often not fully effective and have a high incidence of dose-limiting side effects [10-12]. Thus, the major therapies used to treat arthritic joint pain are nonsteroidal antiinflammatory drugs (NSAIDs) and opioids, which have remained virtually unchanged for decades $[11,12]$.

\section{Disease progression and joint pain}

Currently, our understanding of what drives arthritic joint pain is that joint injury, inflammation, and/or deterioration of the joint causes an increased responsiveness of the joint nociceptors (peripheral sensitization) and of the nociceptive neurons of the CNS (central sensitization) (see $[1,18,19]$ for review). It has been reported that as joint and adjacent bone are injured because of inflammation, nerves that innervate the bone are first activated and sensitized by factors such as bradykinin, prostaglandin $E_{2}$, prostaglandin $I_{2}$, serotonin, substance $\mathrm{P}$, galanin, neuropeptide $\mathrm{Y}$, and nociceptin, which are released by stromal/inflammatory/immune cells in the injured joint (see $[18,19]$ for review). As the joint continues to deteriorate, these "sensitized" nerve fibers then become activated when noxious or nonnoxious mechanical stimuli are applied to the joint (see [1,18-20] for review). As the cartilage deteriorates to the point at which it is no longer intact, bone-on-bone interactions can occur, which may induce direct mechanical stimulation of these sensitized nerve fibers that are present in the adjacent bone $[1,20]$. Paradoxically, if this were the only mechanism driving arthritic joint pain, a clear correlation should appear between joint deterioration/ destruction and joint pain. However, in both trauma and age-related osteoarthritis, a poor correlation is noted between the extent of joint destruction and the frequency and severity of joint pain $[3,21,56]$.

Although these mechanisms certainly contribute to arthritic joint pain, the present data demonstrate that the nerve fibers that innervate the joint are not simply static structures that respond to changes in the joint and bone but rather can undergo a remarkable reorganization in terms of altered morphology, increase in the density of nerve fibers per unit area, and sprouting into areas of the joint that are normally poorly innervated. The populations of nerve fibers that are undergoing

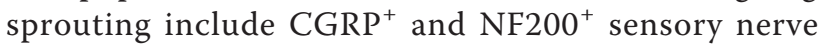
fibers that correspond to unmyelinated/thinly myelinated and thinly myelinated sensory nerve fibers, respectively, as well as $\mathrm{TH}^{+}$postganglionic sympathetic nerve fibers. Previous human [57-69] and rodent $[23,35,46,70-74]$ studies have shown that inappropriate remodeling of sensory and sympathetic nerve fibers can be associated with skeletal $[23,35,46,62,63,68,69,71]$ and nonskeletal pain $[57,60,64-67,72-74]$. As we observed a similar remodeling of sensory and sympathetic nerve fibers in geriatric arthritic knee joints, this pathologic reorganization of nerve fibers would then set in place a neuroanatomic substrate that could drive movement and resting arthritic joint pain.

In addition to the robust sprouting of sensory and sympathetic nerve fibers in the knee joints of the geriatric mice that received injections of CFA, we observed the appearance of neuroma-like structures in the synovium and femoral periosteum. Previous preclinical and clinical studies have shown that injury to peripheral nerves due to trauma, amputation, compression, or surgery can lead to the formation of painful neuromas 


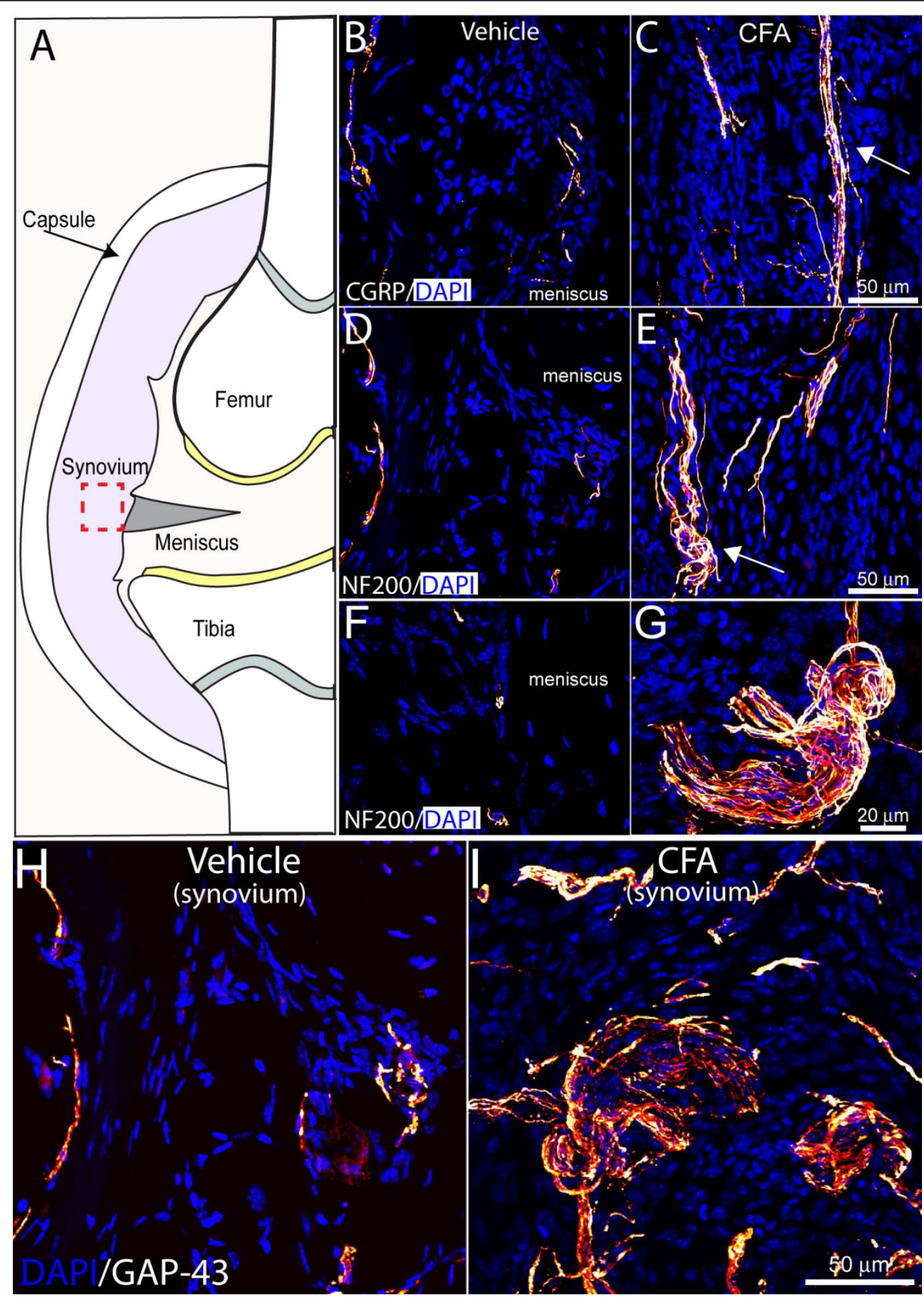

Figure 4 Sensory nerve fiber sprouting and formation of neuroma-like structures in the painful geriatric arthritic knee joint. Schematic of a frontal view of a cross-sectioned mouse knee joint (A). The red square illustrates the synovial region from which the confocal images were obtained. Representative confocal images of calcitonin gene-related peptide $\left(\mathrm{CGRP}^{+}\right)$, neurofilament 200-kDa (NF200 ${ }^{+}$) sensory nerve fibers (yellow/ orange), and growth-associated protein (GAP43; marker of fibers undergo regeneration, yellow/orange) and DAPI-labeled nuclei (blue) in knee-joint sections (20 $\mu \mathrm{m}$ thick) of vehicle-injected (B, D, F, H) and CFA-injected (C, E, G, I) mice. In vehicle-injected mice, a low-level, regular pattern of

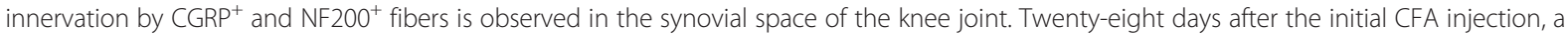
significant number of $\mathrm{CGRP}^{+}, \mathrm{NF}_{200^{+}}$, and $\mathrm{GAP}_{3}{ }^{+}$nerve fibers have sprouted and have a disorganized appearance, as compared with vehicleinjected mice. Note that $\mathrm{CGRP}^{+}, \mathrm{NF}_{200^{+}}$, and $\mathrm{GAP}_{3} 3^{+}$sprouted nerve fibers are localized in the synovium and are not observed in the meniscus of the joint. Furthermore, formation of neuroma-like structures occurred in the synovium of the geriatric mice injected with CFA (G). 


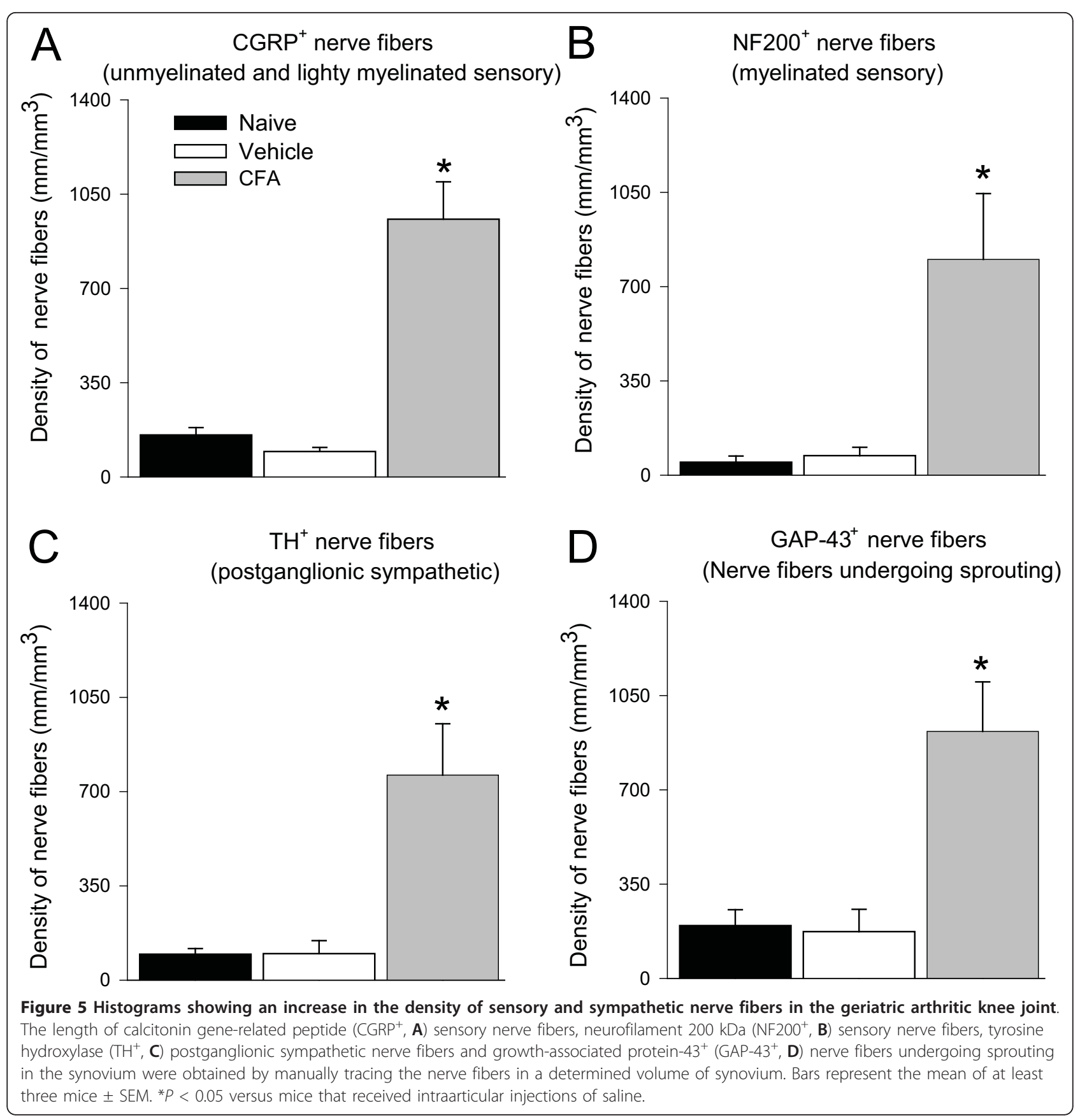

$[58,59,75,76]$, which have a morphology similar to the neuroma-like structures observed in the present study. In humans, these nonmalignant neuromas frequently cause chronic and severe pain $[58,59,77]$, produce spontaneous ectopic discharges [76,78,79], in part by upregulation of sodium channels $[59,80,81]$, and are largely refractory to medical treatment [59]. Whether these neuroma-like structures in the geriatric arthritic knee joints also show an upregulation of sodium channels and produce spontaneous discharges is unknown, but these structures could partially explain the phenomenon of spontaneous arthritic joint pain (pain at rest), as movement would not be required for these spontaneous ectopic and painful discharges to occur.

In addition to the reorganization of nerve fibers in the knee joints of the geriatric mice that received injections of CFA, we found a significant increase in the total number of $\mathrm{CD}^{+} 8^{+}$macrophages/monocytes in the synovium (as the inflamed synovium is much larger than the naïve or sham-operated synovium) but not changes in 


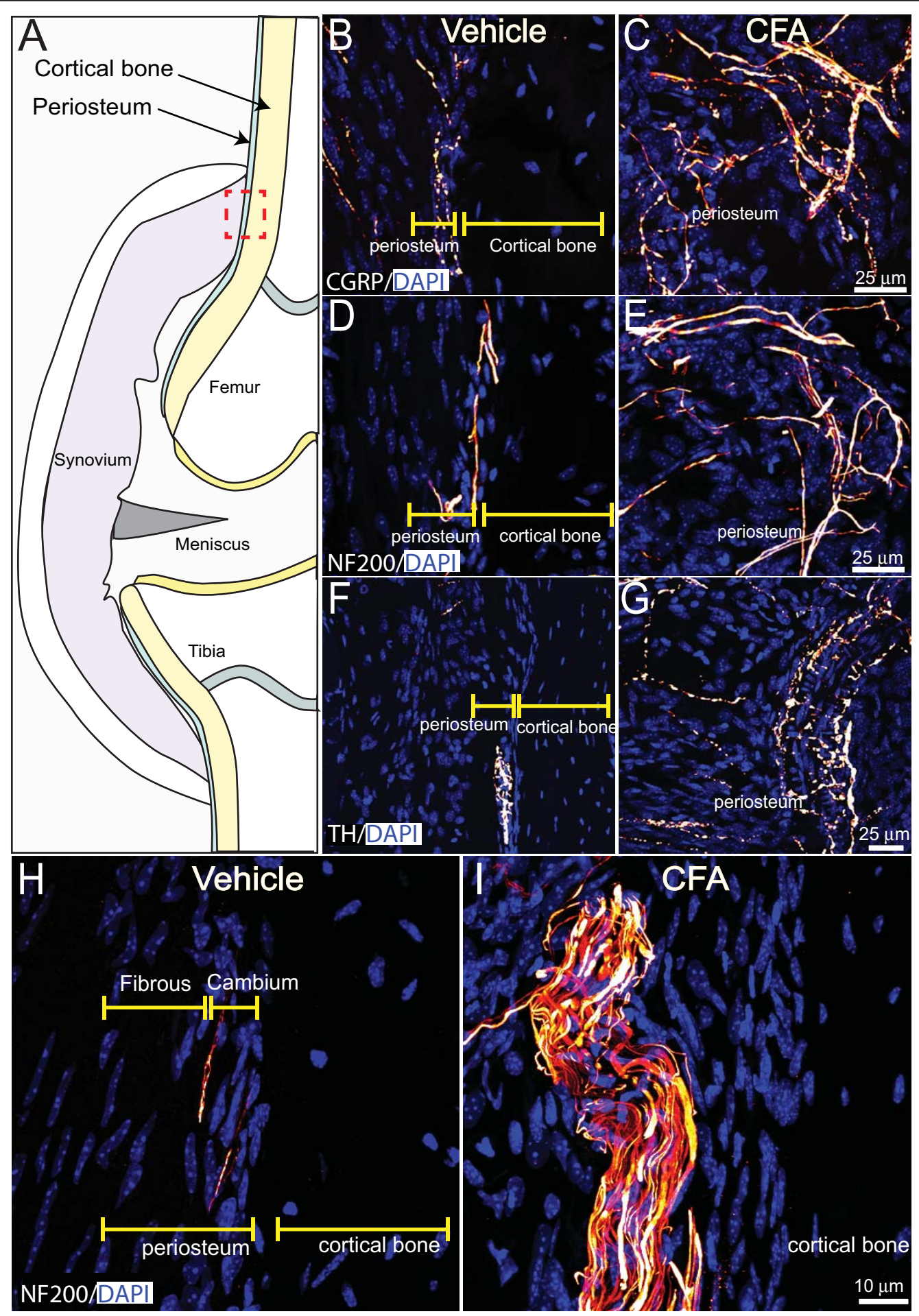

Figure 6 Intraarticular injection of CFA induces nerve sprouting and formation of neuroma-like structures in the periosteum. (A) Schematic of the frontal view of a cross-sectioned mouse knee joint illustrating the periosteal region from which the confocal images were obtained (red square). Representative confocal images of $\mathrm{CGRP}^{+}$and $\mathrm{NF}_{2} \mathrm{OO}^{+}$sensory nerve fibers (yellow/orange), TH sympathetic nerve fibers (yellow/orange), and DAPI labeled nuclei (blue) in $20 \mu \mathrm{m}$-thick knee sections from vehicle-injected (B, D, F, H) and CFA-injected (C, E, G, I) mice. In vehicle-injected mice, a low-level, regular pattern of innervation by CGRP ${ }^{+}$, NF200 ${ }^{+}$, and $\mathrm{TH}^{+}$nerve fibers is observed in the synovial

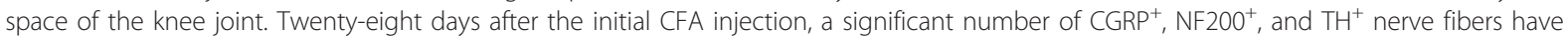
sprouted and have a disorganized appearance as compared with vehicle-injected mice. Furthermore, a formation of neuroma-like structures by NF200 ${ }^{+}$nerve fibers was seen in the femoral periosteum of the geriatric mice injected with CFA (I). 
the density per unit areas of these inflammatory cells. Although the lack of change in macrophage/monocyte density in relation to the difference in total numbers of these cells between the groups is unknown, it is possible that that age-related loss in the macrophage infiltration and function may explain this finding [82].

\section{Sprouting of sensory and sympathetic nerve fibers in the geriatric knee joint}

In general, neuroplasticity is thought to decline with age. For example, a previous study showed that the rate of axonal regeneration as determined by axonal transport of radiolabeled proteins after sciatic nerve injury is slower in 28-month-old rats as compared with 2 - and 10-month old rats [27]. In 24-month-old mice, the number of regenerating myelinated axons in tibial fascicles is significantly reduced ( $50 \%$ decrease) compared with 6 month-old mice after crushing at the sciatic nerve [25]. Additionally, it has been shown that the collateral sprouting of sensory and sympathetic axons after injury is $50 \%$ less in aged rats as compared with young rats [24,26].

In contrast to these studies, our results indicate that sensory and sympathetic nerve fibers that innervate the knee joints of geriatric mice not only retained the capacity to undergo a robust and inappropriate sprouting but they also formed neuroma-like structures after inflammation or injury. One potential explanation as to why the neuronal sprouting of sensory and sympathetic nerve fibers is so robust in the aged knee joint is that an age-related maintenance occurs in the synthesis and release of growth factors from skeletal tissues. In support of this hypothesis, the expression of different growth factors, including bone morphogenetic protein-2, bone morphogenetic protein-7, insulin-like growth factor- 1 , leptin, tumor necrosis factor- $\alpha$, and transforming growth factor- $\beta$ are maintained and/or increased in the intervertebral discs in aged rabbits and humans [83-85]. Additionally, maintenance in the expression and responsiveness of receptors expressed by the nerves innervating the joints may promote the nerve sprouting and neuroma formation observed in the present study.

A key unknown is the factor(s) driving the sprouting and neuroma formation of sensory nerve fibers and ultimately the pain in the painful inflamed joint. Previous reports exhaustively demonstrated that in both the developing and adult animal, nerve growth factor can induce marked sprouting of sensory and sympathetic nerve fibers (see [86] for review). Furthermore, previous studies in our laboratory, using a mouse monoclonal antibody against NGF (anti-NGF), showed that sustained administration of anti-NGF results in a marked reduction of sprouting and neuroma-like formation by CGRP ${ }^{+}, \mathrm{TH}^{+}$, and $\mathrm{NF} 200^{+}$nerve fibers in the tumor-bearing bone, irrespective of whether the tumor synthesizes NGF $[35,46,71]$. These data, together with significant literature suggesting that macrophages, neutrophils, endothelial cells, T-lymphocytes, and fibroblasts can all express significant levels of NGF (see [87] for references), suggest that NGF may be a key factor driving the reorganization of sensory and sympathetic nerve fibers in inflamed knee joints from geriatric mice.

\section{Conclusions}

In this study, CFA-induced inflammation of the geriatric knee joint resulted in significant pain, robust nerve sprouting, and formation of neuroma-like structures in the synovium and periosteum by both sensory (CGRP ${ }^{+}$ and $\left.\mathrm{NF}_{200^{+}}\right)$and sympathetic $\left(\mathrm{TH}^{+}\right)$nerve fibers. Interestingly, these sprouting nerve fibers were present at a higher density and had unique morphology that is never observed in the normal nonpainful geriatric knee joint. Although robust sprouting and neuroma formation are clearly present at 28 days after CFA injection, it remains to be determined when this nerve sprouting and neuroma formation first begins.

As sprouting and reorganization of sensory and sympathetic nerve fibers has been observed in other chronic pain states in both animals and humans [23,35,46,57-71] and has been correlated with the establishment of a chronic pain state, the present data suggest that ectopic sprouting may be involved in the generation and/or maintenance of arthritic pain in the aged joint. Understanding the specific factors that promote the observed nerve sprouting, defining the contribution that ectopic nerve sprouting plays in driving arthritic joint pain, and determining whether this ectopic nerve sprouting is transitory or permanent in nature may provide mechanistic insight and novel pharmacologic targets for more effective control of age-related joint pain.

\section{Abbreviations}

CFA: complete Freund adjuvant; CGRP: calcitonin gene-related peptide; CNS: central nervous system; DAPI: 4',6-diamidino-2-phenyl-indole; GAP43: growthassociated protein-43; NSAIDs: nonsteroidal antiinflammatory drugs; NF200: neurofilament 200 kDa; PBS: phosphate-buffered saline; SEM: standard error of the mean; $\mathrm{TH}$ : tyrosine hydroxylase; TNF-a: tumor necrosis factor-alpha.

\section{Acknowledgements}

This work was supported by the National Institutes of Health grant (NS23970, CA154550, CA157449), by the Department of Veteran Affairs, Veterans Health Administration, Rehabilitation Research and Development Service Grants (04380-I and A6707-R), and by the Calhoun Fund for Bone Pain. The authors thank Magdalena J. Kaczmarska, Gabriela Castaneda-Corral, Aaron Bloom, Katie T. Freeman, Kathleen Coughlin, and Joseph Ghilardi for their excellent technical assistance.

\section{Author details}

${ }^{1}$ Department of Pharmacology, University of Arizona, 1501 N. Campbell Avenue, Tucson, AZ 85724, USA. ²Unidad Académica Multidisciplinaria Reynosa Aztlán, Universidad Autónoma de Tamaulipas, Calle 16 y Lago de Reynosa, Reynosa, 88740, México. ${ }^{3}$ Arizona Cancer Center, University of 
Arizona, 1501 N. Campbell Avenue, Tucson, AZ 85724, USA. ${ }^{4}$ Research Service, VA Medical Center, One Veterans Drive, Minneapolis, MN 55417, USA.

\section{Authors' contributions}

JMJA and PWM participated in the conception and design of the experiments, in the analysis and interpretation of the data, and in the writing of the manuscript. Both authors approved the final version of the manuscript to be published.

\section{Competing interests}

None of the authors of this study claims a conflict of interest.

Received: 7 December 2011 Revised: 15 March 2012

Accepted: 1 May 2012 Published: 1 May 2012

\section{References}

1. Kidd BL: Osteoarthritis and joint pain. Pain 2006, 123:6-9.

2. Dieppe PA, Lohmander LS: Pathogenesis and management of pain in osteoarthritis. Lancet 2005, 365:965-973.

3. Felson DT, Naimark A, Anderson J, Kazis L, Castelli W, Meenan RF: The prevalence of knee osteoarthritis in the elderly: The Framingham Osteoarthritis Study. Arthritis Rheum 1987, 30:914-918.

4. Felson DT, Lawrence RC, Dieppe PA, Hirsch R, Helmick CG, Jordan JM, Kington RS, Lane NE, Nevitt MC, Zhang $Y$, Sowers M, McAlindon T, Spector TD, Poole AR, Yanovski SZ, Ateshian G, Sharma L, Buckwalter JA Brandt KD, Fries JF: Osteoarthritis: new insights; Part 1: the disease and its risk factors. Ann Intern Med 2000, 133:635-646.

5. Helmick CG, Felson DT, Lawrence RC, Gabriel S, Hirsch R, Kwoh CK, Liang MH, Kremers HM, Mayes MD, Merkel PA, Pillemer SR, Reveille JD, Stone $\mathrm{JH}$, National Arthritis Data Workgroup: Estimates of the prevalence of arthritis and other rheumatic conditions in the United States. Part I. Arthritis Rheum 2008, 58:15-25.

6. Woolf AD, Pfleger B: Burden of major musculoskeletal conditions. Bull World Health Organ 2003, 81:646-656.

7. Brooks PM: The burden of musculoskeletal disease: a global perspective. Clin Rheumatol 2006, 25:778-781.

8. Lubeck DP: The costs of musculoskeletal disease: health needs assessment and health economics. Best Pract Res Clin Rheumatol 2003, 17:529-539.

9. Cisternas MG, Murphy LB, Yelin EH, Foreman AJ, Pasta DJ, Helmick CG: Trends in medical care expenditures of US adults with arthritis and other rheumatic conditions 1997 to 2005. J Rheumatol 2009, 36:2531-2538.

10. Lanas A, Tornero J, Zamorano JL: Assessment of gastrointestinal and cardiovascular risk in patients with osteoarthritis who require NSAIDs: the LOGICA study. Ann Rheum Dis 2010, 69:1453-1458.

11. Weinblatt ME: Nonsteroidal anti-inflammatory drug toxicity: increased risk in the elderly. Scand J Rheumatol Supp/ 1991, 91:9-17.

12. Feinberg SD: Prescribing analgesics: how to improve function and avoid toxicity when treating chronic pain. Geriatrics 2000, 55:49-50.

13. Lutz W, Sanderson W, Scherbov S: The coming acceleration of global population ageing. Nature 2008, 451:716-719.

14. Christensen K, Doblhammer G, Rau R, Vaupel JW: Ageing populations: the challenges ahead. Lancet 2009, 374:1196-1208.

15. Papageorgiou AC, Badley EM: The quality of pain in arthritis: the words patients use to describe overall pain and pain in individual joints at rest and on movement. J Rheumatol 1989, 16:106-112.

16. Wagstaff S, Smith OV, Wood PH: Verbal pain descriptors used by patients with arthritis. Ann Rheum Dis 1985, 44:262-265.

17. Charter RA, Nehemkis AM, Keenan MA, Person D, Prete PE: The nature of arthritis pain. Br J Rheumatol 1985, 24:53-60

18. Schaible HG, Ebersberger A, Von Banchet GS: Mechanisms of pain in arthritis. Ann N Y Acad Sci 2002, 966:343-354.

19. Schaible HG, Richter F, Ebersberger A, Boettger MK, Vanegas $H$, Natura $G$, Vazquez E, Segond von Banchet G: Joint pain. Exp Brain Res 2009, 196:153-162.

20. Hunter DJ, McDougall JJ, Keefe FJ: The symptoms of osteoarthritis and the genesis of pain. Med Clin North Am 2009, 93:83-100.

21. Hannan MT, Felson DT, Pincus T: Analysis of the discordance between radiographic changes and knee pain in osteoarthritis of the knee. $J$ Rheumatol 2000, 27:1513-1517.
22. Taylor P, Manger B, Alvaro-Gracia J, Johnstone R, Gomez-Reino J, Eberhardt E, Wolfe F, Schwartzman S, Furfaro N, Kavanaugh A: Patient perceptions concerning pain management in the treatment of rheumatoid arthritis. J Int Med Res 2010, 38:1213-1224.

23. Shinoda M, Honda T, Ozaki N, Hattori H, Mizutani H, Ueda M, Sugiura Y: Nerve terminals extend into the temporomandibular joint of adjuvant arthritic rats. Eur J Pain 2003, 7:493-505.

24. Kuchel GA: Alterations in target innervation and collateral sprouting in the aging sympathetic nervous system. Exp Neurol 1993, 124:381-386.

25. Tanaka K, Webster HD: Myelinated fiber regeneration after crush injury is retarded in sciatic nerves of aging mice. J Comp Neurol 1991, 308:180-187.

26. Kovacic U, Zele T, Mars T, Sketelj J, Bajrovic FF: Aging impairs collateral sprouting of nociceptive axons in the rat. Neurobiol Aging 2010, 31:339-350.

27. Pestronk A, Drachman DB, Griffin JW: Effects of aging on nerve sprouting and regeneration. Exp Neurol 1980, 70:65-82.

28. Gauldie SD, McQueen DS, Clarke CJ, Chessell IP: A robust model of adjuvant-induced chronic unilateral arthritis in two mouse strains. J Neurosci Methods 2004, 139:281-291.

29. Shelton DL, Zeller J, Ho WH, Pons J, Rosenthal A: Nerve growth factor mediates hyperalgesia and cachexia in auto-immune arthritis. Pain 2005, 116:8-16.

30. Lane NE, Schnitzer TJ, Birbara CA, Mokhtarani M, Shelton DL, Smith MD, Brown MT: Tanezumab for the treatment of pain from osteoarthritis of the knee. N Engl J Med 2010, 363:1521-1531.

31. Rojkovich B, Gibson T: Day and night pain measurement in rheumatoid arthritis. Ann Rheum Dis 1998, 57:434-436.

32. Jimenez-Andrade JM, Martin CD, Koewler NJ, Freeman KT, Sullivan LJ Halvorson KG, Barthold CM, Peters CM, Buus RJ, Ghilardi JR, Lewis JL, Kuskowski MA, Mantyh PW: Nerve growth factor sequestering therapy attenuates non-malignant skeletal pain following fracture. Pain 2007, 133:183-196

33. Koewler NJ, Freeman KT, Buus RJ, Herrera MB, Jimenez-Andrade JM, Ghilardi JR, Peters CM, Sullivan LJ, Kuskowski MA, Lewis JL, Mantyh PW: Effects of a monoclonal antibody raised against nerve growth factor on skeletal pain and bone healing following fracture of the C57BL/6J mouse femur. J Bone Miner Res 2007, 22:1732-1742.

34. Honore P, Luger NM, Sabino MA, Schwei MJ, Rogers SD, Mach DB, O'Keefe PF, Ramnaraine ML, Clohisy DR, Mantyh PW: Osteoprotegerin blocks bone cancer-induced skeletal destruction, skeletal pain and painrelated neurochemical reorganization of the spinal cord. Nat Med 2000, 6:521-528

35. Jimenez-Andrade JM, Bloom AP, Stake Jl, Mantyh WG, Taylor RN, Freeman KT, Ghilardi JR, Kuskowski MA, Mantyh PW: Pathological sprouting of adult nociceptors in chronic prostate cancer-induced bone pain. $J$ Neurosci 2010, 30:14649-14656.

36. Jimenez-Andrade JM, Bloom AP, Mantyh WG, Koewler NJ, Freeman KT, Delong D, Ghilardi JR, Kuskowski MA, Mantyh PW: Capsaicin-sensitive sensory nerve fibers contribute to the generation and maintenance of skeletal fracture pain. Neuroscience 2009, 162:1244-1254.

37. Freeman KT, Koewler NJ, Jimenez-Andrade JM, Buus RJ, Herrera MB, Martin CD, Ghilardi JR, Kuskowski MA, Mantyh PW: A fracture pain model in the rat: adaptation of a closed femur fracture model to study skeletal pain. Anesthesiology 2008, 108:473-483.

38. Luger NM, Sabino MA, Schwei MJ, Mach DB, Pomonis JD, Keyser CP, Rathbun M, Clohisy DR, Honore P, Yaksh TL, Mantyh PW: Efficacy of systemic morphine suggests a fundamental difference in the mechanisms that generate bone cancer vs inflammatory pain. Pain 2002, 99:397-406.

39. Kul-Panza E, Berker N: Pedobarographic findings in patients with knee osteoarthritis. Am J Phys Med Rehabil 2006, 85:228-233.

40. Honore P, Mantyh PW: Bone cancer pain: from mechanism to model to therapy. Pain Med 2000, 1:303-309.

41. Castaneda-Corral G, Jimenez Andrade JM, Bloom AP, Taylor RN, Mantyh WG Kaczmarksa MJ, Ghilardi JR, Mantyh PW: The majority of myelinated and unmyelinated sensory nerve fibers that innervate bone express TrkA. Neuroscience 2011, 178:196-207.

42. Ashley JW, Shi Z, Zhao H, Li X, Kesterson RA, Feng X: Genetic ablation of CD68 results in mice with increased bone and dysfunctional osteoclasts. PLOS ONE 2011, 6:e25838. 
43. Katschke KJ Jr, Rottman JB, Ruth JH, Qin S, Wu L, LaRosa G, Ponath P, Park CC, Pope RM, Koch AE: Differential expression of chemokine receptors on peripheral blood, synovial fluid, and synovial tissue monocytes/macrophages in rheumatoid arthritis. Arthritis Rheum 2001, 44:1022-1032.

44. Sung JH, Mastri AR: Aberrant peripheral nerves and microneuromas in otherwise normal medullas. J Neuropathol Exp Neurol 1983, 42:522-528.

45. Devor M, Wall PD: Type of sensory nerve fibre sprouting to form a neuroma. Nature 1976, 262:705-708.

46. Mantyh WG, Jimenez-Andrade JM, Stake Jl, Bloom AP, Kaczmarska MJ, Taylor RN, Freeman KT, Ghilardi JR, Kuskowski MA, Mantyh PW: Blockade of nerve sprouting and neuroma formation markedly attenuates the development of late stage cancer pain. Neuroscience 2010, 171:588-598.

47. Martin CD, Jimenez-Andrade JM, Ghilardi JR, Mantyh PW: Organization of a unique net-like meshwork of CGRP+ sensory fibers in the mouse periosteum: implications for the generation and maintenance of bone fracture pain. Neurosci Lett 2007, 427:148-152.

48. Mach DB, Rogers SD, Sabino MC, Luger NM, Schwei MJ, Pomonis JD, Keyser CP, Clohisy DR, Adams DJ, O'Leary P, Mantyh PW: Origins of skeletal pain: sensory and sympathetic innervation of the mouse femur. Neuroscience 2002, 113:155-166.

49. Jimenez-Andrade JM, Mantyh WG, Bloom AP, Xu H, Ferng AS, Dussor G, Vanderah TW, Mantyh PW: A phenotypically restricted set of primary afferent nerve fibers innervate the bone versus skin: therapeutic opportunity for treating skeletal pain. Bone 2010, 46:306-313.

50. Kido MA, Kiyoshima T, Kondo T, Ayasaka N, Moroi R, Terada Y, Tanaka T: Distribution of substance $\mathrm{P}$ and calcitonin gene-related peptide-like immunoreactive nerve fibers in the rat temporomandibular joint. J Dent Res 1993, 72:592-598.

51. Hukkanen M, Konttinen $Y T$, Rees RG, Santavirta S, Terenghi G, Polak JM: Distribution of nerve endings and sensory neuropeptides in rat synovium, meniscus and bone. Int J Tissue React 1992, 14:1-10.

52. Hukkanen M, Konttinen $Y T$, Rees RG, Santavirta S, Terenghi G, Polak JM: Distribution of nerve endings and sensory neuropeptides in rat meniscus and bone. Int J Tissue React 1992, 14:1-10.

53. Hill EL, Elde R: Distribution of CGRP-, VIP-, DßH-, SP-, and NPYimmunoreactive nerves in the periosteum of the rat. Cell Tissue Res 1991, 264:469-480.

54. Hill EL, Elde R: Calcitonin gene-related peptide-immunoreactive nerve fibers in mandibular periosteum of rat: evidence for primary afferent origin. Neurosci Lett 1988, 85:172-178.

55. Sawatzky R, Liu-Ambrose T, Miller WC, Marra CA: Physical activity as a mediator of the impact of chronic conditions on quality of life in older adults. Health Qual Life Outcomes 2007, 5:68.

56. Bedson J, Croft PR: The discordance between clinical and radiographic knee osteoarthritis: a systematic search and summary of the literature. BMC Musculoskelet Disord 2008, 9:116.

57. Akbar A, Yiangou Y, Facer P, Walters JR, Anand P, Ghosh S: Increased capsaicin receptor TRPV1-expressing sensory fibres in irritable bowel syndrome and their correlation with abdominal pain. Gut 2008, 57:923-929.

58. Lindqvist A, Rivero-Melian C, Turan I, Fried K: Neuropeptide- and tyrosine hydroxylase-immunoreactive nerve fibers in painful Morton's neuromas. Muscle Nerve 2000, 23:1214-1218.

59. Black JA, Nikolajsen L, Kroner K, Jensen TS, Waxman SG: Multiple sodium channel isoforms and mitogen-activated protein kinases are present in painful human neuromas. Ann Neurol 2008, 64:644-653.

60. Ceyhan GO, Bergmann F, Kadihasanoglu M, Altintas B, Demir IE, Hinz U, Muller MW, Giese T, Buchler MW, Giese NA, Friess H: Pancreatic neuropathy and neuropathic pain: a comprehensive pathomorphological study of 546 cases. Gastroenterology 2009, 136:177-186

61. Arnold J, Barcena de Arellano ML, Ruster C, Vercellino GF, Chiantera V, Schneider A, Mechsner S: Imbalance between sympathetic and sensory innervation in peritoneal endometriosis. Brain Behav Immun 2012, 26:132-141.

62. Schubert TE, Weidler C, Lerch K, Hofstadter F, Straub RH: Achilles tendinosis is associated with sprouting of substance $P$ positive nerve fibres. Ann Rheum Dis 2005, 64:1083-1086.
63. Suri S, Gill SE, Massena de Camin S, Wilson D, McWilliams DF, Walsh DA: Neurovascular invasion at the osteochondral junction and in osteophytes in osteoarthritis. Ann Rheum Dis 2007, 66:1423-1428.

64. Tympanidis $P$, Terenghi $G$, Dowd $P$ : Increased innervation of the vulval vestibule in patients with vulvodynia. $\mathrm{Br} J$ Dermatol 2003, 148:1021-1027.

65. Yilmaz Z, Renton T, Yiangou Y, Zakrzewska J, Chessell IP, Bountra C, Anand P: Burning mouth syndrome as a trigeminal small fibre neuropathy: increased heat and capsaicin receptor TRPV1 in nerve fibres correlates with pain score. J Clin Neurosci 2007, 14:864-871.

66. Mukerji G, Yiangou Y, Agarwal SK, Anand P: Transient receptor potential vanilloid receptor subtype 1 in painful bladder syndrome and its correlation with pain. J Urol 2006, 176:797-801.

67. Chan CL, Facer P, Davis JB, Smith GD, Egerton J, Bountra C, Williams NS, Anand P: Sensory fibres expressing capsaicin receptor TRPV1 in patients with rectal hypersensitivity and faecal urgency. Lancet 2003, 361:385-391.

68. Peng B, Wu W, Hou S, Li P, Zhang C, Yang Y: The pathogenesis of discogenic low back pain. J Bone Joint Surg Br 2005, 87:62-67.

69. Freemont AJ, Peacock TE, Goupille P, Hoyland JA, O'Brien J, Jayson MI: Nerve ingrowth into diseased intervertebral disc in chronic back pain. Lancet 1997, 350:178-181.

70. Farmer MA, Taylor AM, Bailey AL, Tuttle AH, Maclntyre LC, Milagrosa ZE, Crissman HP, Bennett GJ, Ribeiro-da-Silva A, Binik YM, Mogil JS: Repeated vulvovaginal fungal infections cause persistent pain in a mouse model of vulvodynia. Sci Trans/ Med 2011, 3:101ra191.

71. Bloom AP, Jimenez-Andrade JM, Taylor RN, Castaneda-Corral G, Kaczmarska MJ, Freeman KT, Coughlin KA, Ghilardi JR, Kuskowski MA, Mantyh PW: Breast cancer-induced bone remodeling, skeletal pain and sprouting of sensory nerve fibers. J Pain 2011, 12:698-711.

72. Lindsay TH, Jonas BM, Sevcik MA, Kubota K, Halvorson KG, Ghilardi JR, Kuskowski MA, Stelow EB, Mukherjee P, Gendler SJ, Wong GY, Mantyh PW: Pancreatic cancer pain and its correlation with changes in tumor vasculature, macrophage infiltration, neuronal innervation, body weight and disease progression. Pain 2005, 119:233-246.

73. Wacnik PW, Baker CM, Herron MJ, Kren BT, Blazar BR, Wilcox GL, Hordinsky MK, Beitz AJ, Ericson ME: Tumor-induced mechanical hyperalgesia involves CGRP receptors and altered innervation and vascularization of DsRed2 fluorescent hindpaw tumors. Pain 2005, 115:95-106.

74. Schweizerhof M, Stosser S, Kurejova M, Njoo C, Gangadharan V, Agarwal N, Schmelz M, Bali KK, Michalski CW, Brugger S, Dickenson A, Simone DA, Kuner R: Hematopoietic colony-stimulating factors mediate tumor-nerve interactions and bone cancer pain. Nat Med 2009, 15:802-807.

75. Kryger GS, Kryger Z, Zhang F, Shelton DL, Lineaweaver WC, Buncke HJ: Nerve growth factor inhibition prevents traumatic neuroma formation in the rat. J Hand Surg Am 2001, 26:635-644.

76. Devor M, Govrin-Lippmann R: Axoplasmic transport block reduces ectopic impulse generation in injured peripheral nerves. Pain 1983, 16:73-85.

77. Devor M: Neuropathic pain: what do we do with all these theories? Acta Anaesthesiol Scand 2001, 45:1121-1127.

78. Devor M, Keller CH, Ellisman MH: Spontaneous discharge of afferents in a neuroma reflects original receptor tuning. Brain Res 1990, 517:245-250.

79. Nystrom B, Hagbarth KE: Microelectrode recordings from transected nerves in amputees with phantom limb pain. Neurosci Lett 1981, 27:211-216.

80. England JD, Happel LT, Kline DG, Gamboni F, Thouron CL, Liu ZP, Levinson SR: Sodium channel accumulation in humans with painful neuromas. Neurology 1996, 47:272-276.

81. Devor M, Govrin-Lippmann R, Angelides K: Na+ channel immunolocalization in peripheral mammalian axons and changes following nerve injury and neuroma formation. J Neurosci 1993, 13:1976-1992.

82. Przybyla B, Gurley C, Harvey JF, Bearden E, Kortebein P, Evans WJ, Sullivan DH, Peterson CA, Dennis RA: Aging alters macrophage properties in human skeletal muscle both at rest and in response to acute resistance exercise. Exp Gerontol 2006, 41:320-327.

83. Murakami H, Yoon ST, Attallah-Wasif ES, Tsai KJ, Fei Q, Hutton WC: The expression of anabolic cytokines in intervertebral discs in age-related degeneration. Spine (Phila 1976) 2006, 31:1770-1774. 
84. Zhao CQ, Liu D, Li H, Jiang LS, Dai LY: Expression of leptin and its functional receptor on disc cells: contribution to cell proliferation. Spine (Phila 1976) 2008, 33:E858-E864.

85. Bachmeier BE, Nerlich AG, Weiler C, Paesold G, Jochum M, Boos N: Analysis of tissue distribution of TNF-alpha, TNF-alpha-receptors, and the activating TNF-alpha-converting enzyme suggests activation of the TNFalpha system in the aging intervertebral disc. Ann N Y Acad Sci 2007, 1096:44-54.

86. Pezet S, MCMahon SB: Neurotrophins: mediators and modulators of pain. Annu Rev Neurosci 2006, 29:507-538.

87. Mantyh PW, Koltzenburg M, Mendell LM, Tive L, Shelton DL: Antagonism of nerve growth factor-TrkA signaling and the relief of pain. Anesthesiology 2011, 115:189-204.

doi:10.1186/ar3826

Cite this article as: Jimenez-Andrade and Mantyh: Sensory and

sympathetic nerve fibers undergo sprouting and neuroma formation in

the painful arthritic joint of geriatric mice. Arthritis Research \& Therapy

2012 14:R101.

\section{Submit your next manuscript to BioMed Central} and take full advantage of:

- Convenient online submission

- Thorough peer review

- No space constraints or color figure charges

- Immediate publication on acceptance

- Inclusion in PubMed, CAS, Scopus and Google Scholar

- Research which is freely available for redistribution

Submit your manuscript at www.biomedcentral.com/submit 